\title{
ОСНОВНІ ПРОБЛЕМИ ФОРМУВАННЯ МЕТОДОЛОГІЇ ІНТЕЛЕКТУАЛЬНОГО НАВЧАННЯ НА ОСНОВАХ ДУХОВНОСТІ ТА МОРАЛЬНОСТІ У СУЧАСНОМУ СУСПІЛЬСТВІ ЗНАНЬ ТА ІНФОРМАЦЇ̈
}

\section{О. В. Немцов}

к. е. н., проф., академік Міжнародної кадрової академії

президент НДО «Міжнародна академія з наукових фундаментальних та прикладних досліджень та розробок»

Основою будь-якого теоретичного та методологічного забезпечення $є$ найвища форма наукового знання теорія. Окрім теорії, в сфері наукових досліджень виокремлюють гіпотезу, аксіому, концепцію, які знаходять своє розкриття в сукупності законів та закономірностей, принципів, методів та засобів, до речі, останні складають основу методичного забезпечення.

Як пише видатний учений Альберт Ейнштейн: «Наука не має довічних теорій. Будь-яка теорія має свій період поступового розвитку та тріумфу, після якого вона може прийти до швидкого занепаду. ...створення нової теорії схоже на збирання на гору, яке відкриває нові та широкі краєвиди, що показують несподівані зв'язки між нашою первинною точкою та ії багатим оточенням» [14, с. 265]. Розвиваючи вищезазначену глибоку за своїм змістом думку, вчена $С$. В. Фрейдіна пише: «Історія розвитку науки свідчить про те, що нова наукова теорія, якою б суперечливою вона не здавалась, не заперечує повністю старої теорії, а надає більш глибокого, повного та єдиного пояснення широкому колу явищ і процесів, по-новому інтерпретує їх, включаючи попередні результати як окремий випадок. ...Наука не склад готових та вичерпних істин, а процес їх досягнення, руху від пізнання обмеженого, приблизного, до все більш загального, глибокого, точного. Такий процес є безмежним» [7, с. 45].

Отже, щодо попереднього вислову, а також практики буття, можна зробити висновок, що теорії взаємодіють одна з одною, і навіть найбільш суперечливі повністю не заперечують одна одну. Так, сьогодні в світі з'явилося і продовжує з'являтися чимало теорій з різних галузей знань, які мають свої точки зіткнення, і тому дослідити той чи інший процес, об'єкт чи явище, використовуючи лише одну теорію стає неможливим, бо в такому випадку буде свідомо збіднюватись багатомірність та багатогранність матеріалу, що вивчається, навмисно спрощуватися, в результаті чого набуті знання будуть некоректними, фрагментарними, що може призвести до неправильного уявлення про предмет дослідження, неправильних висновків і як наслідок, до неправильних дій.

Як було зазначено вище, теорії набувають свого розкриття у сукупності законів та закономірностей, принципів, методів та засобів.

Філософський словник так трактує науковий закон — «це відображення найбільш суттєвих, об' єктивних внутрішніх зв'язків та відносин, які повторюються, у природі, суспільстві, мисленні» [6]. Закономірність Є. В. Фрейдіна визначає, як «об'єктивно існуючу стійку залежність між явищами дійсності, що відповідає певним законам» [7, с. 24]. Отже, різниця між законом та закономірністю на думку авторів Е. В. Мінько та А. Е. Мінько полягає в тому, що «Закономірність багатше закону конкретним змістом: окрім глибоких внутрішніх зв'язків, що відносяться до одного чи декількох законів, вона відображає риси явищ, які зумовлені причинами для даного зв' язку. Закон багатше закономірності тим, що відноситься до більшої маси відповідних явищ, охоплює всю їх сукупність. При цьому просліджується взаємозв'язок між залежністю (як причиннонаслідковим відношенням одного явища до іншого), закономірністю (як об'єктивно існуючими стійкими зв'язками між явищами, їх причинами та наслідками) та законами, що відображають загальні, стійкі відносини, що повторюються, між ними» [4, с. 142-143].

Кожний процес визначається загальними та спеціальними законами. Всі закони можна поділити на дві великі групи - загальні та спеціальні $[3,4,7]$, але деякі автори виокремлюють ще такі групи законів, як всеосяжні загальні [7] та окремі [3]. Загальні закони притаманні всім явищам та процесам, а спеціальні характерні тільки одному чи декільком таким явищам та процесам. Єдиної класифікації законів не існує, кожний автор розглядає їх з точки зору досліджуваного ним явища чи процесу. Дослідження літератури $з$ даної проблематики дозволили дійти висновку, що всеосяжні загальні закони можна віднести до загальних, а окремі закони - до спеціальних. Таким чином, існує певний зв'язок між всіма законами, а їх застосування для того чи іншого процесу, явища чи об’єкту може носити одночасний характер. У роботі Мінько зазначається, що «Між загальними та спеціальними законами існує діалектичний взаємозв'язок: загальні закони діють через спеціальні, а останні являють собою прояв загальних» [4, с. 153].

Отже, загальні всеосяжні закони притаманні для всіх наукових знань, кожної сфери діяльності людини; загальні закони застосовуються в певній науці або певній сфері діяльності людини; окремі закони для певного підрозділу сфери науки стосуються тільки окремої частини певної науки; спеціальні закони застосовуються для конкретних процесів, явищ, об'єктів. 
Серед думок вчених немає єдиної думки щодо визначення принципу, причому деякі дослідники відносять певні закони до принципів, а певні принципи — до законів. У своїй праці О. О. Беляєв та Е. М. Коротков вважають, що «принципи відрізняються від законів гносеологічним походженням. Якщо закон відображає повторюваність стійких зв’язків і відносин, які відбуваються в природних та суспільних явищах, то принцип є оптимальним правилом, нормою, які сформульовані людьми та носять суб'єктивний характер» [1, с. 73].

Єдиної класифікації принципів не існує, оскільки вона, як і класифікація законів, формується дослідником для досягнення власної мети дослідження. Всі принципи також як і закони структуруються таким чином:

- загальнонаукові принципи, які застосовуються в будь-якому дослідженні;

- принципи, які притаманні всім процесам, явищам та об’єктам у певній галузі;

- принципи, що характерні для конкретних процесів, явищ, об'єктів.

Отже, всі принципи взаємопов’язані, причому на основі тверджень деяких із них формуються інші. Отже, каркас принципів складають загальні принципи досліджень, твердження яких є підгрунтям окремих принципів, на основі яких формуються спеціальні принципи.

У філософському словнику метод визначається як: «сукупність дій, прийомів, направлених на досягнення певної мети» [6]. Існує чимало методів, які розрізняються за видами та сферами застосування. Узагальнену класифікацію методів визначити складно, оскільки методи, що застосовуються для дослідження одного об'єкта можуть бути зайвими для іншого.

Таким чином, визначивши основні дефініції, що будуть застосовуватися в подальшому, зазначимо на основні проблеми формування методології інтелектуального навчання.

Сьогодні все більше лунають твердження про необхідність надання уваги духовно-моральному аспекту в процесі безперервної освіти та суспільного розвитку. Формується чимало концепцій, теорій інтелектуального навчання, виховання, культурного розвитку, що мають в своєму підгрунті певні методології та методики. Деякі концепції та теорії в своїх методологіях та методиках містять ідеологічні основи, інші мають в підгрунті так звані загальнолюдські цінності. Все це спричиняє з одного боку надію на якісний розвиток та піднесення, а з іншого насторожує можливими негативними наслідками через хибні імперативи та концепти, що покладені в основу вищезазначених наукових категорій. Отже до формування та формулювання таких наукових категорій, зокрема методології інтелектуального навчання, необхідно ставитися 3 великою обережністю, насамперед з'ясувавши систему критеріїв, за якими вони оцінюватимуся та які концепти та імперативи ні в якому разі не можуть бути в них. Однак розробка системи критеріїв також дуже складний процес без визначення певного базису, першопричини, генеральної мети, основи основ. Таким первісним в цьому процесі можуть бути духовність та їі похідна, наслідок - моральність.

Як зазначають у своєму дослідженні О. Г. Романовський, В. М. Бабаєв, О. С. Пономарьов одним 3 найактуальніших і найглобальніших за своєю значимістю для майбутнього країни, принаймні не меншим ніж розроблення й реалізація ефективної стратегії соціально-економічного відродження, стає завдання відродження духовності, формування культу моральності, знань і культури. Проява релігіозності здебільшого обмежується тільки зовнішніми проявами - виконанням традицій, здійсненням обрядів, носінням атрибутів. Як зазначав митрополит Никодим, найбільш небезпечним є навіть не відкрите відступництво від моралі, справедливості та істини, а більш витончене, приховане, що за апостолом Павлом у посланні до Тимофея «вдає благочестя, сили ж його зріклися». Особливу тривогу викликає культ насильства, жорстокості, зради та розпусти, який пронизує все наше життя. До того ж, до цього згубного впливу особливо схильна молодь, не дивно, що серед неї зростає рівень злочинності. Сьогодні на думку вищезазначених авторів, завдання полягає в тому, щоб, не порушуючи почуттів віруючих, для яких принципово важливі особливості богослужіння й відправлення різноманітних обрядів і святкувань, особливості трактування текстів молитов і священних книг, об'єднати всіх людей, що належать до різноманітних конфесій, щоб вони разом з атеїстами на позиціях толерантності, загальнолюдських духовних і життєвих цінностей, загальнолюдської моралі спрямували свої зусилля на вирішення невідкладних завдань економічного й духовного відродження своєї країни та суспільства.

Отже, як бачимо з наведених висловів, над вищезазначеними питаннями взаємозв'язків людство замислювалося $з$ прадавніх часів, проте і сьогодні доволі складно побудувати адекватну, релевантну модель кількісної залежності між рівнем освіченості та рівнем добробуту, щастя, задоволеності, толерантності, злочинності у суспільстві. Однак за опосередкованими показниками соціологічних досліджень, загальних статистичних спостережень, можна побачити певний тренд, який показує, що чим більшим є ступінь охоплення суспільства освітою та наукою, доступності інформації та комунікаційних каналів, тим кращим за певних застережень на зовнішньополітичні, -економічні, -соціологічні, зовнішньо- та внутрішньоекологічні фактори тощо $є$ рівень добробуту такого суспільства, тим нижчим є рівень злочинності. Ще складнішим питанням $\epsilon$ виявлення моделі кількісної залежності між рівнем духовності, моральності, етичності, культурності суспільства та рівнем добробуту, щастя, задоволеності, толерантності, злочинності в суспільстві. Даному твер- 
дженню можна заперечити: очевидною є причинно-наслідкова залежність між високим рівнем моралі, духовності, етичності та культури у суспільстві та високим рівнем добробуту суспільства, низьким рівнем злочинності, але при більш детальному дослідженні це не є таким очевидним, а залежить, перш за все, від системи цінностей того чи іншого суспільства, народу, тобто це твердження стає коректним за використання певних застережень у розумінні сутності понять моралі та духовності.

Вивчення етимологічних, тлумачних словників, а також інших праць 3 даної тематики надало можливість визначити, що мораль та етика стали відомими у давній античності і вперше були запроваджені древньогрецькими філософами приблизно на межі V-IV ст. до н. е., приблизно через 50-100 років потому такі поняття стають властивими й для застосування древньоримськими філософами та політичними діячами.

Впродовж наступних століть зміст вищенаведених категорій також змінювався: в основному ці поняття інтерпретувалися, осмислювалися, набували нового змісту або уточнювалися у працях філософів, однак в останні століття з появою нових наук, таких як психологія, соціологія, культурологія дані поняття досліджувалися, враховуючи нові контексти та аспекти даних наук. У працях майже кожного філософа поняттям «мораль», «етичність» приділялося доволі багато уваги, зважаючи на їх фундаментальну значущість для всієї парадигми світоглядних концептів, тому ці поняття у кожній праці дуже неординарні, штучні, що ускладнює процес типізації та узагальнення. Проте є два аспекти, за якими у дуже загальному вигляді можна розподілити сутнісну характеристику цих понять: в одному наполягається, що мораль та етика є продуктом суспільного творення, а значить формуються із традицій, звичаїв, правил, ритуалів, обрядів тощо того чи іншого етносу, народу, суспільства, що в більшій мірі відповідає первинному змісту цих термінів; а в іншому доводиться, що мораль і етика є продуктом трансцендентним, тобто сама мораль і етика є притаманними людській надприроді, а тому вони містять у собі певні одкровення людської надсутності, що витікає зі спілкування з Особистістю вищого порядку - у різних релігійних та філософських концепціях даній Особистості (Абсолюту) присвоюються різні властивості та вміння, що більш притаманні для такого поняття як «духовність». Але й у випадку трансцендентальності все одно зазначається у вигляді повторюваної рефлексії вплив на мораль та етичність традицій, звичаїв, правил, ритуалів, обрядів тощо. Отже, як було з’ясовано, у підгрунті моралі та етичності знаходяться елементи культурного шару, творчої волі тієї чи іншої людини, світоглядні уявлення окремого індивіда, народності, етносу. Таким чином, можна висловити застереження, що при використанні морального аспекту у навчанні та вихованні слід спочатку проаналізувати всю систему цінностей, що було покладено у грунт сформованої моралі того чи іншого етносу, народу, суспільства. Це необхідно робити для того, щоб не стати заложником забобонів, атавізмів, хибних світоглядних концептів, які, безумовно, зустрічаються у традиціях, звичаях, правилах, ритуалах, обрядах тощо, що були вироблені впродовж століть та стали елементами моралі. На глобальному рівні розуміння моралі існують так звані загальнолюдські цінності, які в більшій мірі зафіксувалися на рівні різноманітних документів ООН, проте по окремим ціннісним параметрам досі проводяться дискусії і не всім світовим суспільством підтримуються ті чи інші цінності. Таким чином, при формуванні загального концепту моралі необхідно проявляти обережність і вищу мудрість, оскільки наслідки можуть бути доволі тяжкими. У цьому питанні як раз і випливає друга складова — «духовність», яка повинна відігравати головну роль при формуванні моралі та етики.

Етимологічне дослідження «духовності» показало, що це поняття також зароджується у грецькій антич-

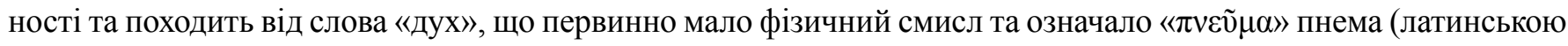
«pneuma» пниума), тобто ефір, тонка субстанція, вітер, вогонь, під чим розумілося дихання живого організму.

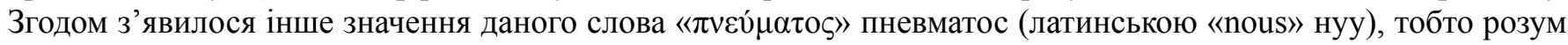
логос, який розуміється як закономірність матеріального космосу, принцип його організації, та представляється як інтелектуальне начало. Останнє трактування даного поняття становиться основним в античній філософії, хоча здебільшого ці два трактування переплітаються та існують разом, як у вигляді розумного начала, так і у вигляді продовження цього розумного начала у більш матеріальнім втіленні у вигляді тонкої субстанції або дихання, тобто чогось ефемерного, пов'язаного з речовими характеристиками. Остання обставина зумовила пізніший переклад грецького «рneuma» на слов’ янський «доухъ», оскільки речовий смисл у цьому грецькому слові також був присутній, тобто перекладачі пов'язали грецьке та слов'янське слово за їх предметним, речовим змістом, однак разом вони доповнили його тією семантичною вертикаллю у вигляді трактування логосу, на формування якого в грецькій культурі пішли сторіччя.

Проте слід зазначити, що подальше становлення понять «дух», «духовність», відбувалося під чималим впливом християнства та набуло вершини розвитку даного концепту саме завдяки останньому, тому й визначальним при трактуванні «духовності» слід визнати християнську концепцію розуміння даного слова. В контексті християнського розуміння духовне трактується як божественне, протиставляючи його в певній мірі матеріальному. «Дух» вже розуміється не як закономірність, за якою розвивається космос, а як Надвсесвітове, Неречове, Надособистість, яка створює Всесвіт за Своєю волею та сам Всесвіт має буття лише в тій мірі, в якій 
він співпричетний до Творця, дух же людини розглядається як дар від Духа Святого, певна співпричетність Йому у вигляді благодатних енергій, що формують особистість, яка має образ та подібність Творця.

В післяантичних філософських працях також зустрічається трактування поняття «дух», що притаманне античності, тобто дух у трактуванні розуму, логосу, особливо це характерно для філософів епохи розвитку механіки, хоча таке трактування зустрічається й у Гегеля у вигляді «ratio» рэйтсио, й у Декарта, Лейбница, Спінози, а також це не протирічить християнському розумінню «Духа», та більш того їх уявлення містять у собі елементи, притаманні християнській філософії, вряди-годи вони по-новому намагаються представити трактування духа як розуму, раціонального начала, вбираючи в себе християнські концепти. У сучасній філософській, психологічній, медичній, культурологічній літературі зустрічаються у дуже загальному смислі такі трактовки «духовності»: моральний світ людини, потреба у красі, прагнення до істини, здатність керуватися вищими ідеалами та цінностями, вміння особистості розуміти своє місце в суспільстві, культурі, усвідомлювати свою єдність 3 народом, власною історією, дія Святого Духа, Божої благодаті у душі людини.

Виходячи з вищевказаного, існує чимало підходів до визначення духовності, але найбільш чітко виокремлено за характеристиками С. П. Штумпф наступні: аксіологічний, соціокультурний, гуманітарний, інформаційно-віртуальний.

3 точки зору аксіологічного підходу духовність є специфічною формою актуалізації людського потенціалу, що містить у собі три напрямки дії: інтелектуальний (когнитивний), морально-сакральний, художньо-естетичний, — всі вони створюють ціннісне наповнення духовного екзистенціалу людського буття.

Основою інтелектуального пізнання є енергійна першооснова інтелекту, що притаманне людині імпліцитно, іiі рушійною силою є воля, активно-дійова основа, що організує процес формування духовності: через зовнішню інформацію формуються внутрішні потенції, настанови, смисли людини, що мотивують поведінкудіяльність до розвитку, відбувається осмислення людиною процесу власного життєтворіння, позитивне зпредметчення ідей, пошук власного Я, прагнення поділитися почуттям краси, зміна свого життя у відповідності до уявлень про те, як повинно бути.

Морально-сакральний напрямок міститься у процесі осмислення та переживання особистого життєвого досвіду, що приводить до пошуку можливості задоволеного буття, до досягнення духовної досконалості, до осмислення добровільного підпорядкування універсальним правилам спільного проживання, до стану персональної свободи та відповідальності, виконанню загальнолюдського, загальнодуховного обов'язку у бутті.

Художньо-естетичний напрямок виражається у задовільнені ідеальної потреби пізнання, а саме задовольняє соціальні потреби людини у справедливості, необхідності здійснення безкорисних дій для іншої особистості.

За соціокультурним підходом духовність ототожнюється із світоглядом, підгрунтям якого $є$ питання про смисл життя, призначені у світі, про вище та нижче у людському бутті, про спроможність до творіння, виражає систему цінностей та ідеалів особистості, соціуму, є ментальною основою культури, духом епохи, формою саморозуміння та особистого росту людини.

Гуманітарний підхід визначає духовність як єдність мотиваційного та результативного простору буття. Під першим розуміється життя, здоров'я, свобода, гідність та незалежність особистості, під другим — досвід людини та іiі творча основа.

За інформаційно-віртуального підходу інформаційно-віртуальна реальність є відображеною дійсністю, похідною від первинної, тобто яка не існує у природі, але присутня у мисленні людини, те, що особистість уявляє, як вона мислить, це образ відображення духовної інформації, частина віртуального світу людини. При взаємодії суб'єкту та об'єкту, в свідомості суб'єкту виникає інформація через що у нього складається ії віртуальний образ, таким чином засвоєна інформація стає особистісними характеристиками, аксіологічним орієнтиром буття. Отже дійсність існує поза нашої свідомостю, є у природі, визначає таке положення, яке дійсно є. Дійсний Всесвіт створений, у ньому відбуваються процеси, що не залежать від діяльності людини. Реальність є сукупністю образів, що виникають у нашій свідомості при сприйнятті зовнішнього світу, створена людиною в результаті отримання інформації та її віртуальному відображені, тобто вона містить у собі не тільки саму даність, але також і об’єкт сприйняття та ставлення особистості до такої даності.

Вбачається, що моральний світ людини, потреба у красі, прагнення до істини, здатність керуватися вищими ідеалами та цінностями, вміння особистості розуміти своє місце в суспільстві, культурі, усвідомлювати свою єдність 3 народом, власною історією — це аспекти більш притаманні поняттю «моралі» та «етичності», «духовність» же направлена на дію зсередини людини, вона є більш особистим трансцендентальним актом спілкування з Творцем, що приводить до самопізнання, самоідентифікації, саморозвитку, самодосконалості, самозцілення, це $є$ синтезом дії вільної волі людини і благодатних дарів Творця, їх симфонією, що направлена на виправлення злих та формування позитивних глибинних мотивів, що спричиняють подальші дії людини, які й реалізуються в моральній сфері. 
Звідси випливає ще застереження: в основі моралі та етичності повинна знаходитися духовність, що є результатом преображення особистості людини через вільну співпрацю, співтворчість людини і Творця у прагненні трансцендентально змінитися, що відображається у кардинальній перебудові ціннісних орієнтирів та як наслідок у зміні образу життя.

Таким чином, зважаючи на те, що духовність повинна знаходитися в основі формування методології інтелектуального навчання, цікавим $є$ дослідження праць філософів, теологів або богословів в сфері концептуальних властивостей природи людини, зокрема ії духовної складової, визначенні ними окремих законів, принципів, методів та механізму або процесу дії духовної складової в людині, ії зав'язків з матеріальною, фізичною складовою.

Сімеон Новий Богослов пише: «Душа всякої людини є словесним образом Слова. Святий Григорій Палама зазначає: «Людській природі Він також дав славу божественності, але божої природи не дав» [9, с. 33]. Слава Божа розуміється як божественна енергія, завдяки якій ми знаходимо Бога у собі, вона поєднує людину з Богом. Максим Сповідник пише: «Святий Дух присутній у кожному з тих, хто існує, особливо в тих, хто якимось чином пов'язаний зі Словом. Оскільки Він проникає у всіх, наскільки це можливо, пробуджуючи у кожному природний розум, через який надає пізнання гріховності» [9, с. 33]. Дух, надчасове та надпричинне у людині визначає й пов'язує, онтологічно закріпляє всі процеси психіки. У Священному Переданні можна знайти дві точки зору на структуру людини: дихотомічну та трихотомічну. Відповідно дихотомія представляє людське єство як протилежність зовнішньої та внутрішньої людини, де зовнішня людина представлена тілом, а внутрішня - душею та духом. Душа за своїм походженням є особливою, вищої в світі істотою, не земною, а надсвітовою, небесною, повністю несхожою з тілом. Дух же вважається вищою частиною душі, Іреней Ліонський та Іван Златоуст часто розуміли під духом благодатний дар Святого Духа. Трихотомія визначає людину як тримірність тіла, душі та духа, тобто зазначаються розбіжності між духом та душею. Найбільш поширеною вважається точка зору про певну частковість тотожності душі та духа, «серединність» душі, тобто душа - це нижча духовна істота, що має певну спроможність до духовного життя. Кіпріан Керн зазначає: «Ветхоадамівське гріховне єство не є першоосновою людини - гріх тільки увійшов у людську природу, проте не $\epsilon$ її вічною сутністю. Більш прадавнім за гріховне начало в людині $\epsilon$ мислення Бога про неї... Це те «небесне людство», що знаходиться у основі кожної людини та більш глибоке за адамівську її зіпсованість... Якщо гріховне у людині є емпіричною реальністю, то вічне небесне людство є самою антологією знаннь про людину. Генеалогія іiї міститься у тієї небесної людини, з якою Логос Божий поєднаний у вічності» [9, с. 38]. Виходячи з цього розрізняють три стани людини, які можна розглядати як етапи ії розвитку:

Природне, від творіння людини до гріхопадіння (людина була не причетна до зла, цілісна та цнотлива, в ній жило та діяло суцільне добро, Творець наділив людину владою на світом, що мало втілення, зокрема, через здатність людини бачити сутність всього іншого ніж людина та ангельський світ творіння, та відповідно до цього називати це творіння).

Нижче за природне, занепале після гріхопадіння (людина втрачає первинну цілісність, розум відділяється від серця та стає безсердечним, а серце нерозумним, спотворюється ієрархія у ії трихотомії: духу вже не підпорядковується душа, а душі - тіло, цей стан характерний здебільшого для сучасної людини. Зло в людині змішується та зливається з природним добром, занепале єство вражене сліпотою розуму, воно не бачить свого падіння, не бачить своїх гріхів, але жорстко судить та засуджує ближніх, починається генезис самості).

Надприродне, відновлене зціленням людини Христом (занепала людина отримує можливість, завдяки хресному подвигу Христа, перейти у надприродний, відновлений стан, відновлене єство має знання та здатність бачити гріх та зло, бачить зло у собі, людях і демонах та перебуває неоскверненим від зла, поступово відбувається відновлення трихотомії, відновлення втраченої цілісності).

Природа душі людини за Феофаном Авсеневим поєднує у собі три ступені неречового буття:

1. Рослинну (часткове розуміння проявів тіла - дихання, питання, родотворіння).

2. Тваринну (спостереження плотського світу, плотські бажання, довільна діяльність).

3. Людську розумну (пізнання Істини, Краси, Добра).

Чимало теологів та богословів виокремлюють три основних сили душі:

1. Дратівлива або затята.

2. Бажаюча, жадаюча.

3. Розумна або словесна.

«У розумній душі є воля, совість, розум і сила любові - в них спочиває Бог», — зазначає Макарій Єгипетський.

Крім вищезазначених трьох сил виокремлюються також інші сили, які називаються органами душі та співвідносяться зі всіма психічними явищами, що зустрічаються у сучасній філософії: волею, мотивацією, 
емоціями, почуттями, розумом, мисленням, пам'яттю, увагою, фантазією, уявленням, органами відчуттів (сенсорикою).

С. Л. Рубінштейн зазначає, що суб'єктивною формою існування потреб (мотивів) є емоції, тобто мотивація суб'єкта проявляється у вигляді емоційних станів, переживань, що сповіщають йому про певну значимість об'єкту та збуджують направити на нього діяльність, а значить емоційні переживання є підсумковою результативною формою існування потреб (мотивів). Отже умови, предмети та явища, що сприяють задоволенню потреб та досягненню цілей, викликають позитивні емоції, а ситуації, що перешкоджають реалізації потреб, досягненню мети викликають негативні емоції та переживання. Як пишуть Л. Ф. Шеховцова та Ю. М. Зєнько, емоції постають як взаємозв'язк між потребами (мотивами) і особливістю ситуації та сповіщають суб'єкту про можливість або неможливість задоволення його потреб у даних умовах, тобто відображають відношення між потребами та можливістю їх успішної реалізації. В. І. Слободчіков та Є. І. Ісаєв проголошують, що потреба є станом пасивно-активним: пасивним, оскільки вказує на залежність людини, а активним, оскільки містить у собі прагнення до задоволення потреби. Виходячи зі ступеня розуміння, прагнення уособлюється бажанням, безпредметним та незрозумілим, або побажанням, коли людина розуміє, що їй бажано, або мотивом, предметною потребою. К. Ізард виокремлює десять фундаментальних емоцій:

- зацікавленість (збудження);

- радість;

- $\quad$ здивування;

- $\quad$ горе (страждання);

- гнів;

- огида;

- зневага;

- страх;

- copom;

- $\quad$ провина (каяття).

Крім того, як зазначають В. І. Слободчіков та С. І. Ісаєв, окрім емоцій (ситуативних станів) існують емоційні процеси:

- афекти (сильні, короткострокові емоційні стани, які часто супроводжуються звуженням свідомості);

- настрої (стійкі емоційні стани, які виражені слабо);

- пристрасті (сильні, глибокі, емоційні переживання, які є домінуючими);

- почуття (стійкі, узагальнені переживання).

Таким, чином вищезазначені емоційні стани та процеси лежать у основі потреб та мотивів, в тому числі й духовних, однак процедура задоволення духовних потреб може проходити як з позиції душі, так і з позиції тіла, проте, результат відрізняється, інколи абсолютно антономічно.

Існує чимало думок авторів що відносити до духовних потреб. Найбільш популярною сьогодні $є$ класифікація потреб та мотивів А. Маслоу. Так, до духовних потреб він відносить соціальні потреби, потреби у повазі та самоповазі, потреби у самореалізації та самоактуалізації, метамотивацією він вважає потребу у зростанні. Цікавими є дослідження психологів, що тяжіють гуманістичного напрямку. Е. Фромм до основних духовних потреб людини відносить потреби у взаємовідносинах (любові); у орієнтації (розумінні світу); у піднесені над тваринними потребами; потребу мати корені (братерство); потребу бути індивідуальним. К. Роджерс вбачає основні духовні потреби у безумовному позитивному відношенні (любові); у самоактуалізації.

Дослідивши за зовнішніми їі проявами особливості будови душі, можна зазначити, що духовними потребами душі є прагнення діяти, насолоджуватися, знати. В ідеальному їх задоволені та розумінні потреба у знанні заспокоюється світлом Істини - внутрішнім свідоцтвом про Бога (Абсолюта), насолоджуватися у баченні Божої краси, діяти - у силі добра, зміцненні волі у боротьбі зі злом. Іншими словами, дані потреби можна звести до єдиної - перебуванні у любові, тобто до прагнення бути у взаємовідносинах з ідеальною, єдиною істиною Любов'ю, якою є Абсолют, а через те перебувати у стані постійного удосконалення любові по відношенню до всього творіння.

Виходячи з представленого бачення смислу духовних потреб людини, можна сказати, що вони є сталими та не змінюються у безкінечності.

Таким чином, визначені філософами та теологами (богословами) закони, принципи, методи та механізми або процеси дії духовної складової у людині, їі зав’язки зі своєю матеріальною, фізичною складовою повинні стати основою формування теорії та методології інтелектуального навчання на основах духовності та моральності. 


\section{Література}

1. Беляев А. А., Коротков Э. М. Системология организации / под ред. С. М. Короткова. М. : ИНФРА-М, 2000.182 с.

2. Краснопеева Е. С. Концепт «духовность»: понятийная и значимостная составляющие сквозь призму переводного дискурса // Вестник Челябинского государственного университета. Челябинск, 2016. № 9 (391). Филологические науки. Вып. 102. С. 93-103.

3. Лафта Дж. К. Теория организации : учеб. пособие. М. : ТК Велби : Проспект, 2003. 416 с.

4. Минько Э. В., Минько А. Э. Теория организации производственных систем : учеб. пособие. М. : Экономика, 2007.493 с.

5. Романовський О. Г., Бабаєв В. М., Пономарьов О. С. Проблеми формування особистості лідера. Х. : Майдан, 2000. 193 с. + 15 кольор. іл.

6. Философский энциклопедический словарь / сост. Л. Ф. Ильичев, П. Н. Федосеев, С. М. Ковалев, В. Г. Панов. М. : Наука, 1983. 840 с.

7. Фрейдина Е. В. Исследование систем управления : учеб. пособие / под ред. Ю. В. Гусева. М. : Омега-Л, 2008.367 с.

8. Фромм Э. Искусство любви. Душа человека. М. : Изд-во «Республика», 1992.

9. Шеховцова Л. Ф., Зенько Ю. М. Элементы православной психологии: монография. М. : Изд-во МПС-ТСЛ, 2012.252 с.

10. Штумпф С. П. Духовность // Аксиологическая направленность и социокультурная природа феномена / Краснояр. гос. пед. ун-т им. В. П. Астафьева. Красноярск, 2010. 176 с.

11. Штумпф С. П. Духовность // Аксиологическая направленность и социокультурная природа феномена / Краснояр. гос. пед. ун-т им. В. П. Астафьева. Изд. 2-е, доп. и перераб. Красноярск, 2013. 256 с.

12. Штумпф С. П. Социально-философский анализ феномена духовности Изд. 2-е, доп. и перераб. Иркутск : Изд-во ИГУ, 2012. 199 с.

13. Штумпф С. П. Феномен духовности (социально-философский анализ). Иркутск : Иркут. гос. ун-т, 2010.108 с.

14. Эйнштейн А. Физика и реальность. М. : Наука, 1965. 360 с. 